\title{
Optimizing Reactor Parameters to Achieve Higher Process Yield in Ex-Situ Oil Shale Process
}

\author{
Dr. Hassan Golpour*, Anand Alembath **, Dr. Joseph D. Smith *** \\ * (Department of Chemical and Biomolecular Engineering, North Carolina State University, Raleigh, NC USA) \\ ** (Department of Chemical and Biochemical Engineering, Missouri University of Science and Technology Rolla, \\ MO USA) \\ *** (Department of Chemical and Biochemical Engineering, Missouri University of Science and Technology \\ Rolla, MO USA)
}

\begin{abstract}
Declining worldwide crude oil reserves and increasing energy needs have the attentions focused on developing existing unconventional fossil fuels including oil shale. America's richest oil shale deposits are found in the Green River Formation of western Colorado, eastern Utah and south-western Wyoming. The current work describes process simulation of an ex-situ oil shale pyrolysis process in a pyrolytic reactor using a novel method involving external and internal heating to increase heat transfer and mixing ratio inside the reactor.

Efforts to improve process yield for commercial operation relies on first developing a complete Aspen based process model of a proposed shale refining plant, identifying the key process parameters for the reactor and then optimizing the overall process. Simulation results are compared to earlier experimental data collected from a pilot scale rotary reactor operated by Combustion Resources Inc. (CR). This work identified the critical impact of bed temperature on crude production in such a way that for a bed temperature of less than $400^{\circ} \mathrm{C}$, results showed less than $10 \%$ conversion in crude production and for bed temperatures between 450 and $500^{\circ} \mathrm{C}$, above $90 \%$ conversion was achieved.

The proposed model consists of four zones including drying, shale reactions, natural gas combustion and gas/oil recovery. Different cases were defined and studied based on various operational conditions. Optimized operational values for the key parameters including reactor temperature, reactor volume and feed rate were given as results to maximum shale oil production.

Keywords: Alternative Fuel, Aspen Simulation, Oil Shale, Optimization, Pyrolysis, Unconventional Hydrocarbons
\end{abstract}

\section{INTRODUCTION}

Oil shale is a sedimentary rock which under a high temperature process in a very low controlled amount of oxygen called "pyrolysis" starts to devolatilize a combustible fuel gas called "synthesis gas" which further could be converted to liquid fuel or a variety of useful chemicals in a chemical refinery. Kerogen has a high hydrogen-to-carbon ratio, giving it the potential to be superior to heavy oil or coal as a source of liquid fuel [1]. Shale breaks into thin pieces with sharp edges. It occurs in a wide range of colours that include: red, brown, green, grey, and black [2]. Three different samples of shale are shown in Fig 1. In ex-situ process, oil shales are mined and crushed to fine particles before processing as shown in Fig 2 [3].

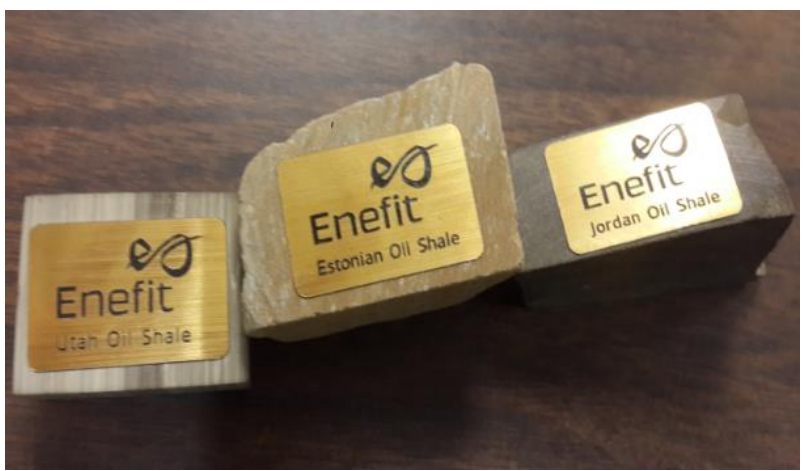

Figure 1 - Different samples of oil shale at Missouri S\&T ERDC lab. Left to right: Utah oil shale, Estonian oil shale, Jordan oil shale 


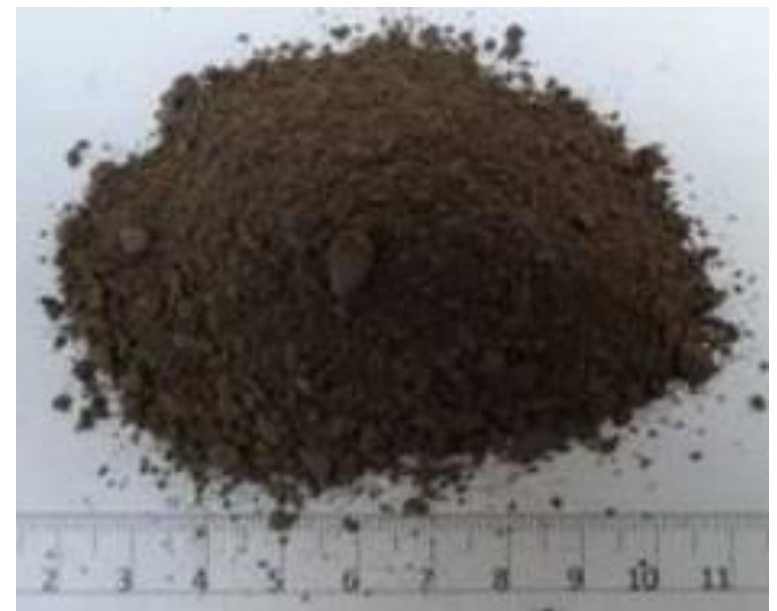

Figure 2 - Crushed Oil Shale

Oil shale is spread across the world. United States of America has the highest deposit of oil shale [4] as shown in Fig 3 [5]. This hydrocarbon resource represents a major energy reserve and can increase U.S. energy security and support sustained economic growth. Various extraction processes have been developed but none yet has been commercialized to produce synthetic crude from oil shale deposit. Australia's attempt to commercialise oil shale plant has been through the Stuart Oil Shale Project developed by Southern Pacific Petroleum NL [6]. Stuart Oil Shale plant and Paraho indirect heating model are shown in Fig 4 [7] and Fig 5 [8].

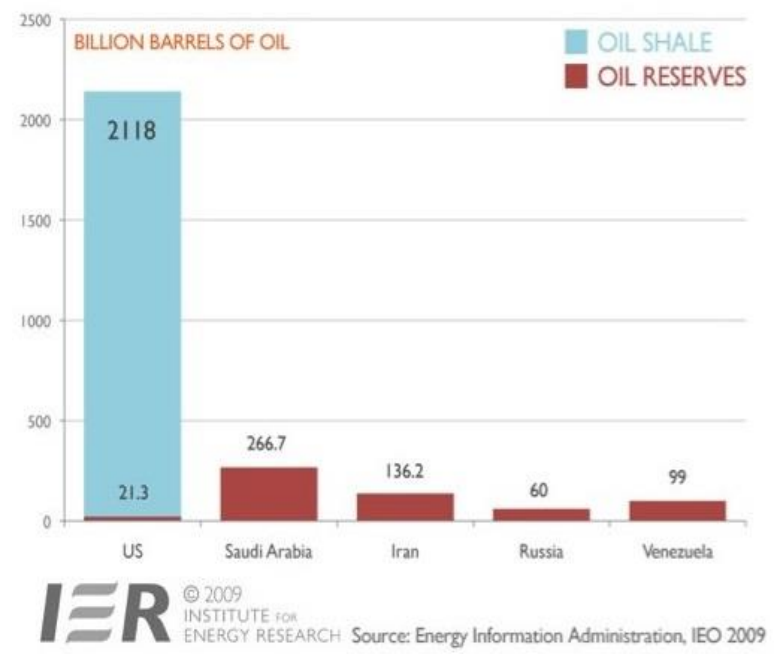

Figure 3 - Comparison of US oil shale resources with foreign oil reserves

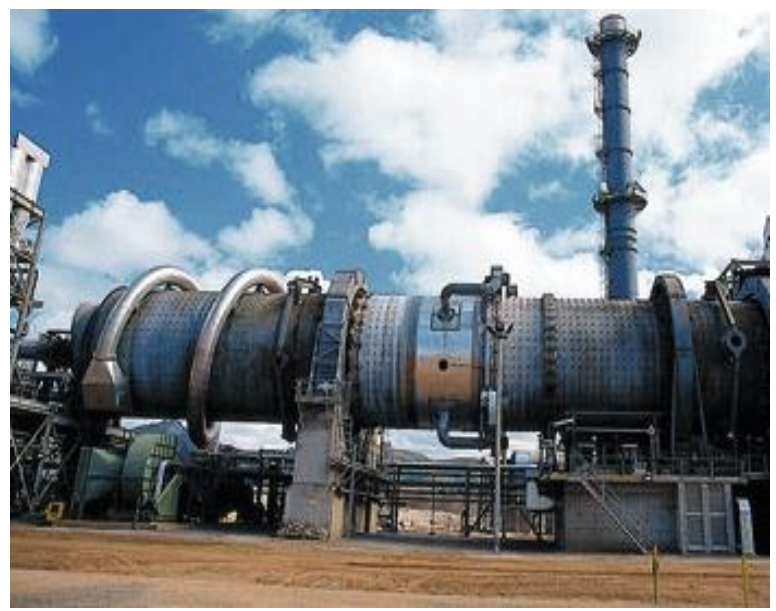

Figure 4 - Stuart Shale Oil Plant

This study shows how changing reactor parameters would affect the overall performance of oil shale processing, and it is based on simulation of the ex-situ process of oil shale by an indirectly heated rotary reactor at CR Inc. facility in Provo, UT [11]. Combustion chamber consists of air inlets and natural gas nozzles. Energy released from natural gas combustion process is transferred to reactor by convection and conduction heat transfer. In the drying zone of the reactor, crushed raw shale particles $(<2 \mathrm{~mm})$ are mixed with recycle stream of spent shale which act as a heat carrier. Spent shale as a by-product, is heated to $\left(300-600^{\circ} \mathrm{C}\right)$. The spent shale could be used as granular fill or sub-base in cement industry [9]. Experimental results at the CR pilot plant concluded that the residence time decreases with increased mass flow, but not substantially. Also, it was observed that having a constant heat duty from combustion resource, increasing the feed rate led to lower spent shale temperature and lower shale oil conversion percentage $[10,11]$.

The United States Government and Environmental Protection Agency (EPA) are planning to regulate high carbon dioxide tax to control green gas house emission in power plants. When the reactor is operating below a certain temperature, the release of $\mathrm{CO}_{2}$ from carbonates for green river basin oil shale is very low [12]. Increase in the reactor temperature slightly above this specific temperature would produce significantly more $\mathrm{CO}_{2}$, thus it is important to study how bed temperature affects the release of $\mathrm{CO}_{2}$. CR process is known to release $<10 \%$ carbon dioxide and is shown in Fig 6 [10]. 


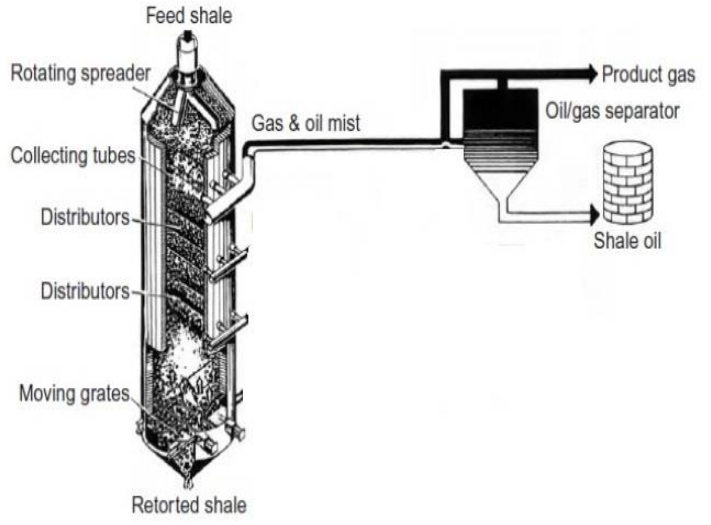

Figure 5 - Paraho retort - indirect heating model

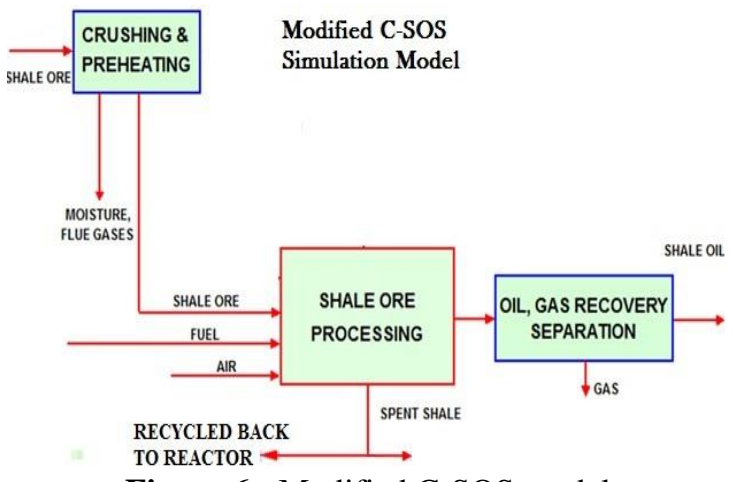

Figure 6 - Modified C-SOS model

\section{ASPEN MODEL}

Aspen Simulation was used to model the exsitu oil shale process and optimize the reactor parameters to achieve higher yield. Drying zone, shale reaction zone, combustion zone and oil/gas recovery zone were simulated separately and finally integrated into one model as shown in Fig 7.

\subsection{Drying Zone}

Green river oil shale typically consists of $1-2 \%$ moisture by weight. Due to low moisture content, the heat duty required for drying zone is not comparable to reaction zone. A heater and a water vapour separator describe the drying section with the heat duty provided from the natural gas combustion zone. The duty from the natural gas burner was split between the drying zone and reaction zone using F-Split. The splitter ratio was set in such way that there was no moisture content in the oil shale feed stream into pyrolysis reactor. The parameters which control the flash separation in the heater are pressure and heat duty. Pressure drop was set to zero and heat duty was controlled by natural gas consumption rate. Before entering the pyrolysis reactor, oil shale feed stream typically has a temperature range between 370 and $400 \mathrm{~K}$.

\subsection{Shale Reaction Zone}

Reaction zone is the essence and core of oil shale process. Oil shale typically has $20 \%$ hydrocarbon, $1-2 \%$ moisture and the rest consists of carbonaceous minerals. There are two kinds of reactions taking place in reaction zone. One is the pyrolysis where the Kerogen is converted into light gas and heavy oil. The other one is the decomposition of minerals which is a major contributor to carbon dioxide emission.

In Aspen simulation there are different types of streams defined, which have to be carefully selected. We chose to have a Mixed, Non-Conventional and CI solid stream (MIXNICI) .Oil shale stream is defined as a combination of all these three streams. Moisture is defined as a Mixed stream whereas Kerogen and char as a non-conventional stream and minerals were introduced in a $C I$ solid stream. Elemental analysis of Kerogen and char are shown in Table 1 [13].

Table 1 - Elemental analysis of Kerogen and char

\begin{tabular}{|l|l|l|}
\hline Component \% & Kerogen & Char \\
\hline Carbon & 80.972 & 87.066 \\
\hline Hydrogen & 10.193 & 3.069 \\
\hline Nitrogen & 2.361 & 5.686 \\
\hline Oxygen & 5.393 & 2.320 \\
\hline Sulfur & 1.081 & 1.86 \\
\hline
\end{tabular}

\subsubsection{Pyrolysis reaction}

Using a kinetic CSTR reactor, the pyrolysis reaction is modelled on the basis of Diaz and Braun model for a staged, fluidized bed oil-shale retort with lift-pipe combustor [14]. According to the model:

$R(k)=k \cdot F k o \cdot\left(\frac{F k}{F_{k}}\right)^{n}$

Where:

$\mathrm{T}$ is in Kelvin

$R(k)=$ Kerogen reaction rate, $\mathrm{kg} / \mathrm{m}^{3} . \mathrm{s}$

$k=$ rate constant $=6.9 * 10^{10} \mathrm{e}^{((-21790) / \mathrm{T})}, \mathrm{s}^{-1}$

$F k_{0}=$ Initial Kerogen concentration, $\mathrm{kg} / \mathrm{m}^{3}$ shale

$F k=$ Final Kerogen concentration, $\mathrm{kg} / \mathrm{m}^{3}$ shale .

$n=$ reaction order $=1.4$

The production of gas, oil, and char from Kerogen pyrolysis is calculated by means of stoichiometric factors, as shown below [2]:

$R=f . R(k)$

$f=$ stoichiometric factor of $(\mathrm{kg}$ product $/ \mathrm{kg} . \mathrm{s})$

$R=$ reaction rate $\left(\mathrm{kg}\right.$ product $\left./ \mathrm{m}^{3} . \mathrm{s}\right)$

Since hydrocarbon reaction model is not pre-defined in Aspen plus, the model was written in FORTRAN subroutine [15]. The Stoichiometry for the reaction components were modified and are shown in Table 2 [15]. 


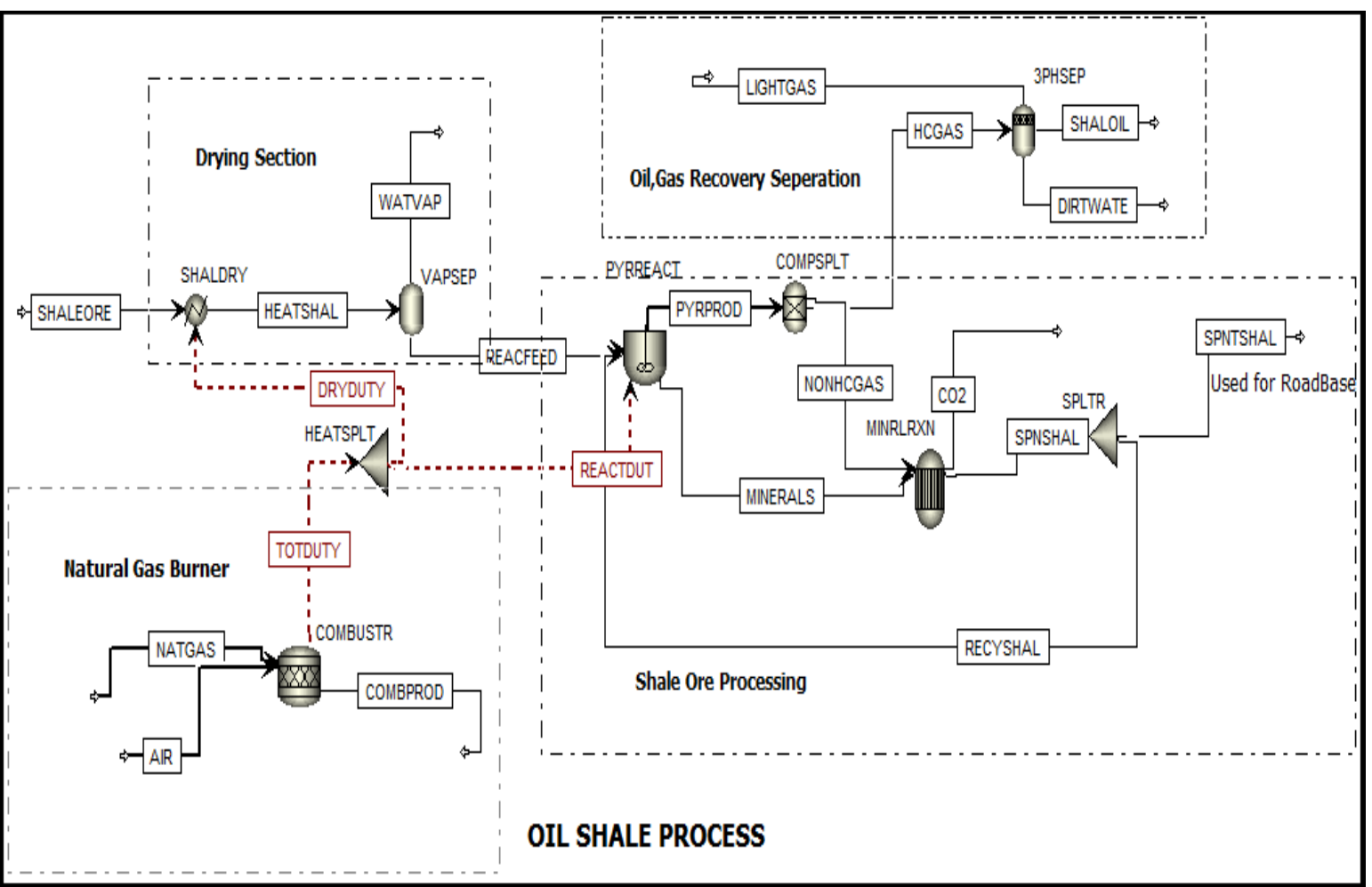

Figure 7 - ASPEN simulation model

Table 2 - Stoichiometry for reaction components

\begin{tabular}{|l|l|}
\hline Components & Stoichiometry \\
\hline $\mathrm{H}_{2}$ & 0.0010 \\
\hline $\mathrm{H}_{2} \mathrm{O}$ & 0.0268 \\
\hline $\mathrm{H}_{2} \mathrm{~S}$ & 0.0010 \\
\hline $\mathrm{NH}_{3}$ & 0.0010 \\
\hline $\mathrm{CO}$ & 0.0057 \\
\hline $\mathrm{CO}_{2}$ & 0.0359 \\
\hline $\mathrm{CH}_{4}$ & 0.0142 \\
\hline $\mathrm{C}_{2} \mathrm{H}_{6}$ & 0.0118 \\
\hline $\mathrm{C}_{3} \mathrm{H}_{8}$ & 0.0117 \\
\hline $\mathrm{C}_{4} \mathrm{H}_{10}$ & 0.0117 \\
\hline $\mathrm{OIL}$ & 0.4767 \\
\hline $\mathrm{CHAR}$ & 0.4025 \\
\hline
\end{tabular}

\subsubsection{Mineral decomposition}

The Minerals considered in this model were based on the green river oil shale composition given by Brons.et al.1989, shown in Table 3 [4]. The mineral reactions for the above inorganics defined in Table 3 are given as follows:

Analcite: $\mathrm{NaAlSi} 2 \mathrm{O} 6 . \mathrm{H}_{2} \mathrm{O} \rightarrow \mathrm{NaAlSi} 2 \mathrm{O} 6+\mathrm{H}_{2} \mathrm{O}$

Siderite: $3 \mathrm{FeCO}_{3} \rightarrow \mathrm{FE}_{3} \mathrm{O}_{4}+\mathrm{CO}+2 \mathrm{CO}_{2}$

Illite: $\mathrm{K}\left(\mathrm{Al}_{2}\right)\left(\mathrm{Si}_{3} \mathrm{Al}\right) \mathrm{O}_{10}(\mathrm{OH})_{2} \rightarrow \mathrm{KAlSi}_{3} \mathrm{O}_{8}+\mathrm{Al}_{2} \mathrm{O}_{3}+$

$\mathrm{H}_{2} \mathrm{O}$

High Temperature Reactions

Dolomite: $\mathrm{CaMg}\left(\mathrm{CO}_{3}\right)_{2} \rightarrow \mathrm{CaCO}_{3}+\mathrm{MgO}+\mathrm{CO}_{2}$

Calcite: $\mathrm{CaCO}_{3} \rightarrow \mathrm{CaO}+\mathrm{CO}_{2}$
Table 3 - Composition of oil shale

\begin{tabular}{|l|c|c|}
\hline Component & MW g/gmol & wt \% Dry basis \\
\hline Siderite & 115.9 & 2.4 \\
\hline Dolomite & 184.4 & 22.8 \\
\hline Calcite & 100.1 & 14.1 \\
\hline Illite & 398.3 & 10.9 \\
\hline Analcime & 220.2 & 0.9 \\
\hline Dawsonite & 144.0 & 0.6 \\
\hline Pyrite & 120.0 & 1.6 \\
\hline Quartz & 60.1 & 13.2 \\
\hline Albite & 262.2 & 13.7 \\
\hline Kerogen & 19.8 \\
\hline Total & 100.0 \\
\hline
\end{tabular}

Mineral reactions are thermal decomposition reactions so, it was desired to find the temperature range which results in minimum carbon dioxide emission. The mineral reactions were thermodynamically modelled using Gibbs reactor. Reaction equilibrium was calculated based on minimizing Gibbs free energy. Both mineral and pyrolytic reactors were maintained at same temperature in each case. Using a component splitter, the products exiting the pyrolytic reactor were separated into two streams called hydrocarbon gas and non-hydrocarbon gas which include $\mathrm{H}_{2} \mathrm{~S}, \mathrm{NH}_{3}$, $\mathrm{CO}$ and $\mathrm{CO}_{2}$. The $\mathrm{HC}$ gases were transported to a recovery section whereas the rest of gases are sent into the mineral decomposition reactor. In real 
process there are only two outlets coming out of the reactor: 1. gas, and 2. spent shale (solid residue). In this simulation we considered three outlets which include: hydrocarbon products, carbon di-oxide and spent shale solids.

\subsection{Natural Gas Combustion and Spent Shale Recycle Stream}

The energy required for pyrolysis reaction is provided by the natural gas burners. To simulate that, natural gas was premixed with air and sent to combustion chamber to produce thermal energy for oil shale reaction and drying zones. In addition to heat, carbon dioxide and water are the other products of natural gas consumption. To reduce the cost of natural gas consumption and further carbon dioxide emission, one approach was to recycle the spent shale back to the reactor as a heat carrier to increase heat transfer and also the mixing ratio in raw feed stream. The amount of spent shale recycled was an important factor which was very much dependent on of the feed flow rate and volume of the reaction zone (reactor).

\subsection{Oil/Gas Recovery Section}

To extract shale oil from produced hydrocarbon gas, an oil recovery section was modelled. In this section, a flash separator was used with a temperature of $300 \mathrm{~K}$ to do the condensation process. After condensation process, almost $80 \%$ of hydrocarbon gas went to liquid and rest were light gases. The flash separator has three outlets: 1. light gas, 2. shale oil, and 3. water.

\section{SIMULATION RESULTS}

The results of the simulation are presented below in four different cases, each one having different controlled and manipulated variables to find the optimum value for the desired responding parameter.

\subsection{Case 1:}

Fixed Volume, Fixed Feed Rate, Variable Temperature

Volume of pyrolytic reactor: $0.05 \mathrm{~m}^{3}$

Feeding rate of oil shale: 26 tons/day (tpd)

The objective of this run was to find the optimum reactor bed temperature for the oil shale process. We defined the optimum point here as the point of maximum shale oil production at comparatively minimum carbon dioxide emission. Kerogen conversion occurs between $600 \mathrm{~K}$ and $873 \mathrm{~K}$ so, reactor temperature was varied between $600 \mathrm{~K}$ and $1273 \mathrm{~K}$ for this case. Even though both reactors were simulated separately, but their temperatures were always kept identical. The heat duty required for the reactors determined the rate of natural gas consumption in combustion block. Therefore, sensitivity analyses were performed in Aspen to obtain the rates of shale oil production, light gas production, natural gas consumption and total carbon dioxide emission (from shale pyrolysis, mineral decomposition and natural gas combustion) corresponding to the change in reactor temperature. Results are shown in Fig 8.

Since the pyrolysis reaction was kinetically modelled in Aspen therefore, it was a function of temperature. As shown in Fig 8, it is noticeable that the Kerogen conversion increased from $600 \mathrm{~K}$ to $900 \mathrm{~K}$ and became steady and after $900 \mathrm{~K}$.

The carbon dioxide emission on the other hand had more critical points. The largest contribution of carbon dioxide came from calcite and dolomite decomposition. Excluding carbon dioxide produced from natural gas combustion, the rate of carbon dioxide emission only from reaction zone (shale pyrolysis and mineral decomposition) is shown in Fig 9. The two critical points were at $673.15 \mathrm{~K}$ and $1098.15 \mathrm{~K}$ which first point is where the dolomite decomposition started and $1098 \mathrm{~K}$ is where the calcite decomposition occurred. Calcite decomposition typically occurs between $1133 \mathrm{~K}$ and $1283 \mathrm{~K}$ [4]. The dolomite decomposes to calcite which further decomposes to $\mathrm{CaO}$ and $\mathrm{CO}_{2}$ at $1098.15 \mathrm{~K}$. This is why a sudden jump is observed at 1123.15K. According to Fig 8 which represents the data in Table 1 in Appendix A, the optimum temperature for maximum oil production $(2.35 \mathrm{tpd})$ at reasonably low $\mathrm{CO}_{2}$ emission (4.91 tpd) was found to be $873 \mathrm{~K}\left(600^{\circ} \mathrm{C}\right)$. 


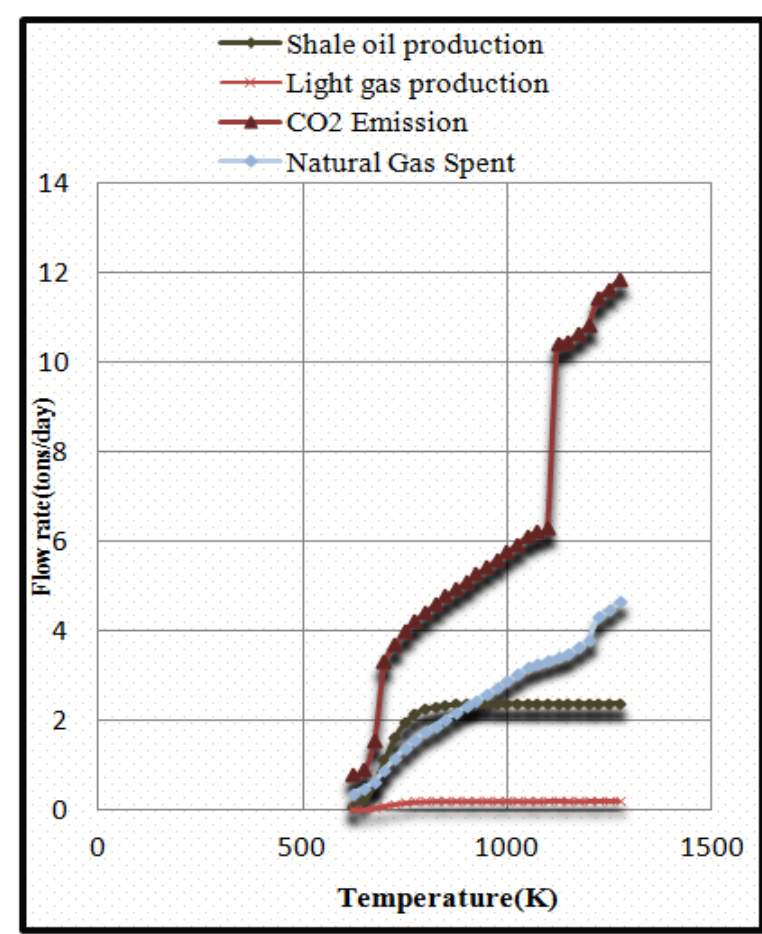

Figure 8 - Production rates of shale oil and light gas, total $\mathrm{CO}_{2}$ emission, and consumption of natural gas

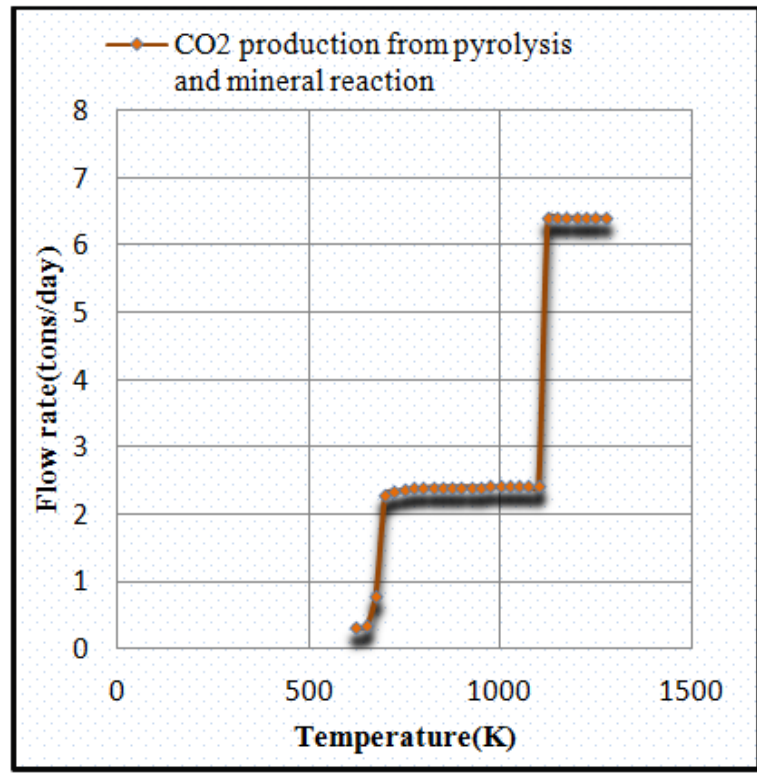

Figure $9-\mathrm{CO}_{2}$ production only from pyrolysis and mineral reactions

\subsection{Case 2:}

Fixed Volume, Limited Heat Duty, Fixed Temperature,

\section{Variable Feed Rate}

Volume of reactor: $0.05 \mathrm{~m}^{3}$

Reactor temperature: $600^{\circ} \mathrm{C}$

Limited reactor heat duty: $1.46 \mathrm{E} 6 \mathrm{BTU} / \mathrm{hr}$
The objective of this run was to find the optimum feed rate for a given reactor volume. The volume was fixed as $0.05 \mathrm{~m}^{3}$ and the temperature considered to be the optimum temperature found from results of case $1,600^{\circ} \mathrm{C}$. Feed rate of raw shale changed from 5 to 50 tpd with a step change of 5 tpd. As feed rate increases, residence time goes down but as far as enough heat is supplied from combustion block, the conversion remains the same and shale oil production increases proportionately. This, in reality is possible but limited. What actually happens is when the feed rate is increased, the required heat duty increases as well but natural gas burners have limited capacity to supply heat. So, the limit for heat duty was assumed to be $1.46 \mathrm{E} 6 \mathrm{BTU} / \mathrm{hr}$. It was observed that the above chosen heat duty was sufficient to keep the reactor temperature constant at $600^{\circ} \mathrm{C}$ for a feed rate of $25 \mathrm{tpd}$.

As feed rate goes beyond $25 \mathrm{tpd}$, the shale oil production increases accordingly if there is no constraint on heat duty. To consider the limited capacity of natural gas burners, heat duty was fixed at $1.46 \mathrm{E} 6 \mathrm{BTU} / \mathrm{hr}$ and simulation were run for different flow rates. As shown in Fig 10, the shale oil production increased with as feed rate was increased. When feed rate reached $40 \mathrm{tpd}$, there was a decline in the shale oil production due to very low reactor temperature. Having a constant heat supply, as feed rate went up, pyrolysis reactor temperature started to decrease as shown in Fig 11. Since both pyrolysis and mineral reactors had to be maintained at the same temperature, the ASPEN calculated temperature for pyrolytic reactor was recorded in each run and applied to the mineral decomposition reactor. This also provided a good estimation of the $\mathrm{CO}_{2}$ emission.

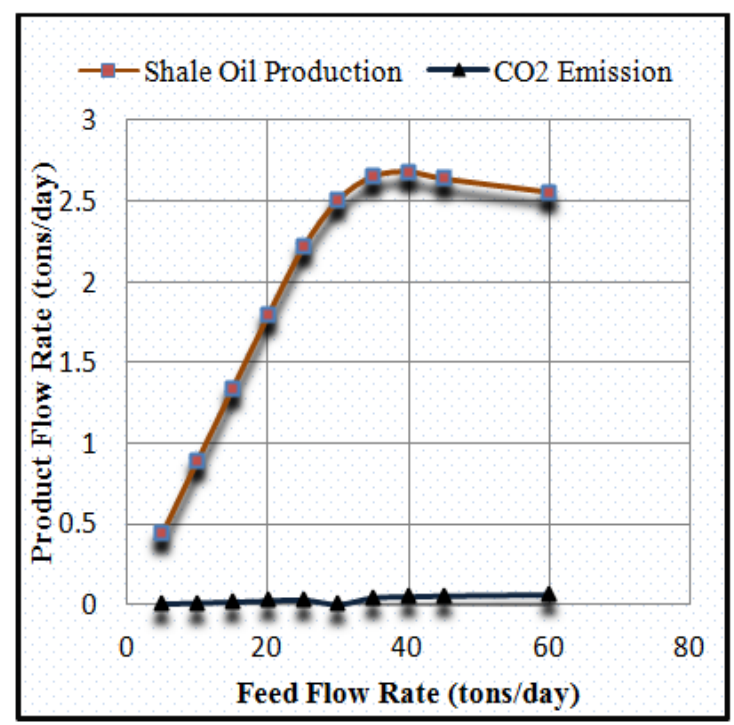

Figure 10 - Optimizing flow rate 
Based on the results, the optimum feed rate for a reactor volume of $0.05 \mathrm{~m}^{3}$ and maximum heat supply of $1.46 \mathrm{E} 6 \mathrm{BTU} / \mathrm{hr}$, was $40 \mathrm{tpd}$, where reactor temperature was $455^{\circ} \mathrm{C}$ and shale oil was produced at a rate of $2.68 \mathrm{tpd}$.

In case 1 , the optimum reactor temperature was obtained for a fixed reactor volume and a constant feed rate. In case 2, the optimum flow rate was achieved for a fixed reactor volume, constant reactor temperature, and a limited heat supply. Next, is to find the best combination of reactor temperature and feed rate to maximize shale oil production for a fixed volume reactor with limited heat supply, which is discussed in case 3 .

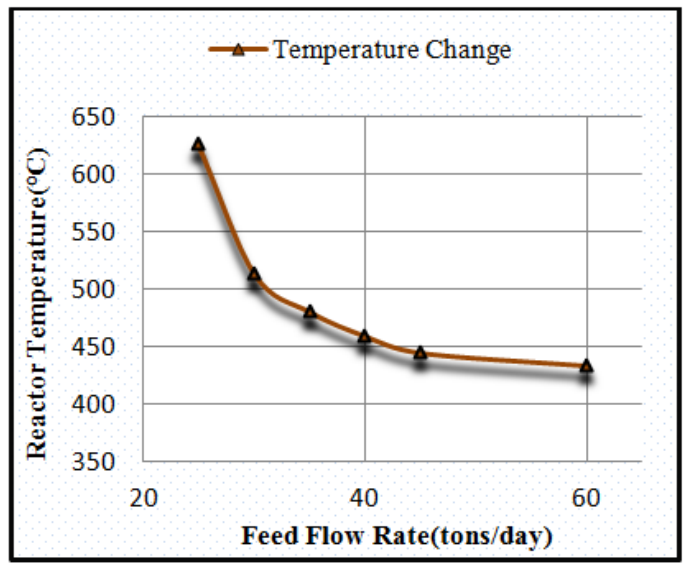

Figure 11 - Reactor temperature vs. feed rate at fixed heat duty

3.3 Case 3:

Fixed Volume, Limited Heat Duty

Variable Temperature, Variable Feed Rate

Reactor volume: $0.05 \mathrm{~m}^{3}$

Limited reactor heat duty: $1.46 \mathrm{E} 6 \mathrm{BTU} / \mathrm{hr}$

The procedure for case 3 was similar to case 2 instead, for each temperature, different feed rates were assumed to find the best treatment combination of temperature and feed rate which provides us the maximum shale oil production. Results are shown for separate temperatures in Fig 12.

At $350^{\circ} \mathrm{C}$, shown in Fig $12(\mathrm{a})$, the shale oil production peaked at 0.3 tpd which is very low. At $400^{\circ} \mathrm{C}$, shown in Fig $12(\mathrm{~b})$, shale oil production climbed to $2.2 \mathrm{tpd}$. This showed, $50^{\circ} \mathrm{C}$ rise in temperature had an enormous impact on shale oil production but, other noticeable factor was the reduction in the feed rate at the peak point. In Fig 12(a), the shale oil production peaked at $100 \mathrm{tpd}$ feed rate but in Fig 12(b) the peak happened at feed rate of $80 \mathrm{tpd}$. As the temperature increases, the shale oil production increases while the feed rate decreases to meet the limited heat supply.

As emphasized above, the temperature is a crucial factor. It was concluded that shale oil production peaks at a point where the temperature is maximum for provided energy. Hence, given an energy supply constraint to the system, there is an optimum point for temperature and flow rate at which shale oil production maximizes. After analysing all the data regarding case 3 presented in Tables 3, 4, 5, 6, 7 and 8 in Appendix A, it was concluded that for a $0.05 \mathrm{~m} 3$ reactor volume and a maximum heat duty of $1.46 * \mathrm{E} 6 \mathrm{BTU} / \mathrm{hr}$ from natural gas burner, the maximum shale oil production was 2.68 tpd for a combination of 40 tpd shale feed rate and reactor temperature of $458^{\circ} \mathrm{C}$.

\subsection{Case 4:}

Fixed Temperature, Fixed Feed Rate, Limited Heat Duty, Different Reactor Volume Limited reactor heat duty: $1.46 E 6$ BTU/hr Flow rate: 40 tpd

The objective of case 4 was slightly different from others. Since the reactor volume cannot be changed or be optimized once the plant is built, case 4 was focused on designing the size of the reactor before fabrication. In a situation where we are going to build a new oil shale reactor, the most important constrain that needs to be identified is maximum energy supply. As in previous cases, a natural gas burner was considered which can provide a maximum heat duty of $1.46 \mathrm{E} 6 \mathrm{BTU} / \mathrm{hr}$ to the reactor. Another parameter which should be in a reasonable range is the feed rate. Using results from case 2, the feed rate was fixed at $40 \mathrm{tpd}$. The reactor temperature was set at $450^{\circ} \mathrm{C}$. Maximum shale oil production with minimum reactor volume were the desired unknown results in this case. The shale oil production gradually increased as the reactor volume increased. Once, the heat duty limit was reached, increasing the reactor volume resulted in decrease in the temperature. Shale oil production was not increasing significantly after this point. So, as shown in Fig 13, the optimum reactor volume was $0.07 \mathrm{~m}^{3}$ with a shale oil production of $2.80 \mathrm{tpd}$. It was also observed that as the reactor volume was increased at maximum heat duty, the reactor temperature started to decrease but the shale oil production was still increasing. Now in this situation, cost is another important factor to be considered. Larger reactors means more material and more cost. Also, the rate of increase in shale oil production slowed down after heat supply limit was reached. In this case, to find the optimum reactor size, the price of products (shale oil, light gas and spent shale) and the cost of material to build the reactor have to be known. 
Dr. Hassan Golpour et al. Int. Journal of Engineering Research and Application www.ijera.com ISSN: 2248-9622, Vol. 7, Issue 4, (Part -1) April 2017, pp.81-93
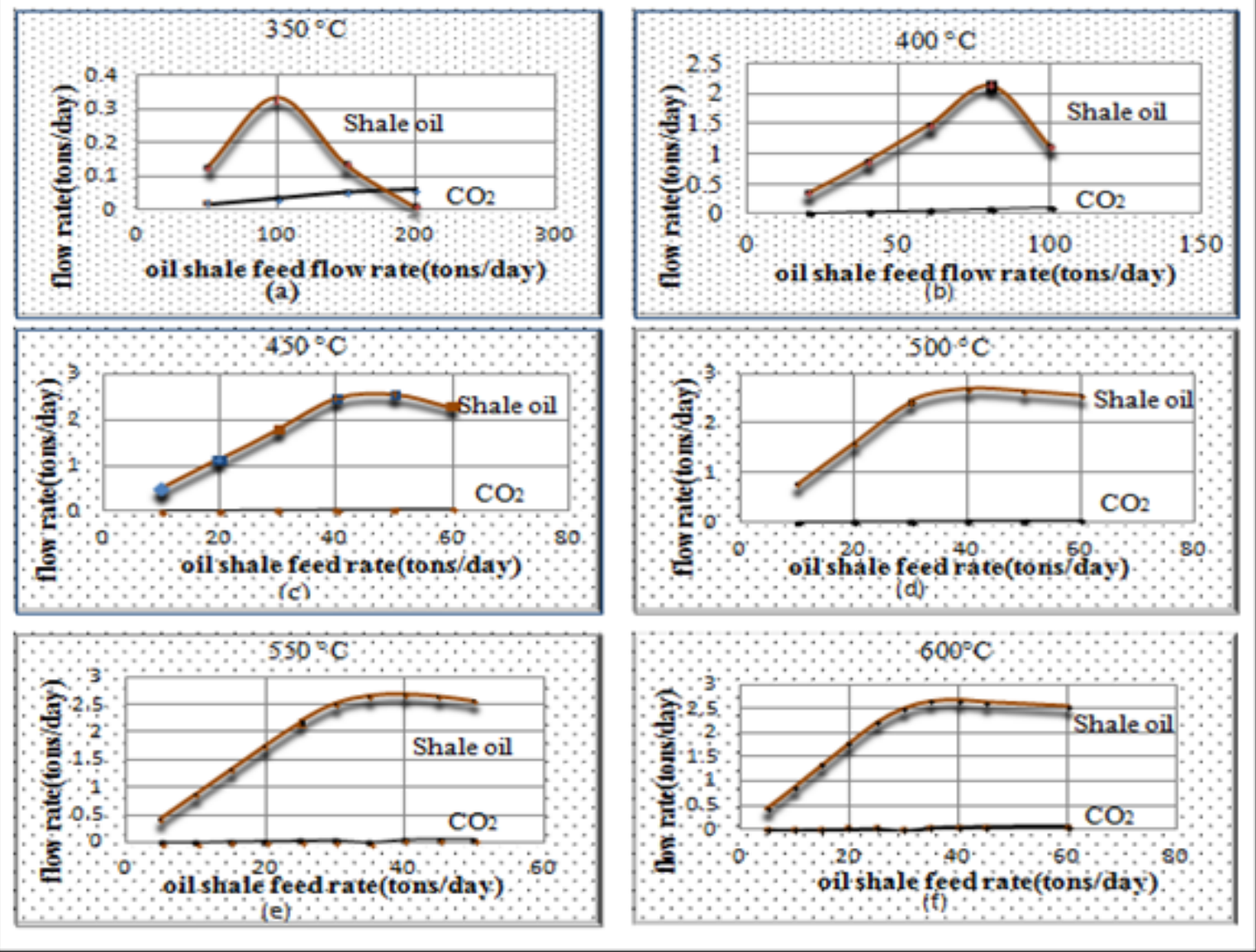

Figure 12 - Optimizing temperature and flow rate

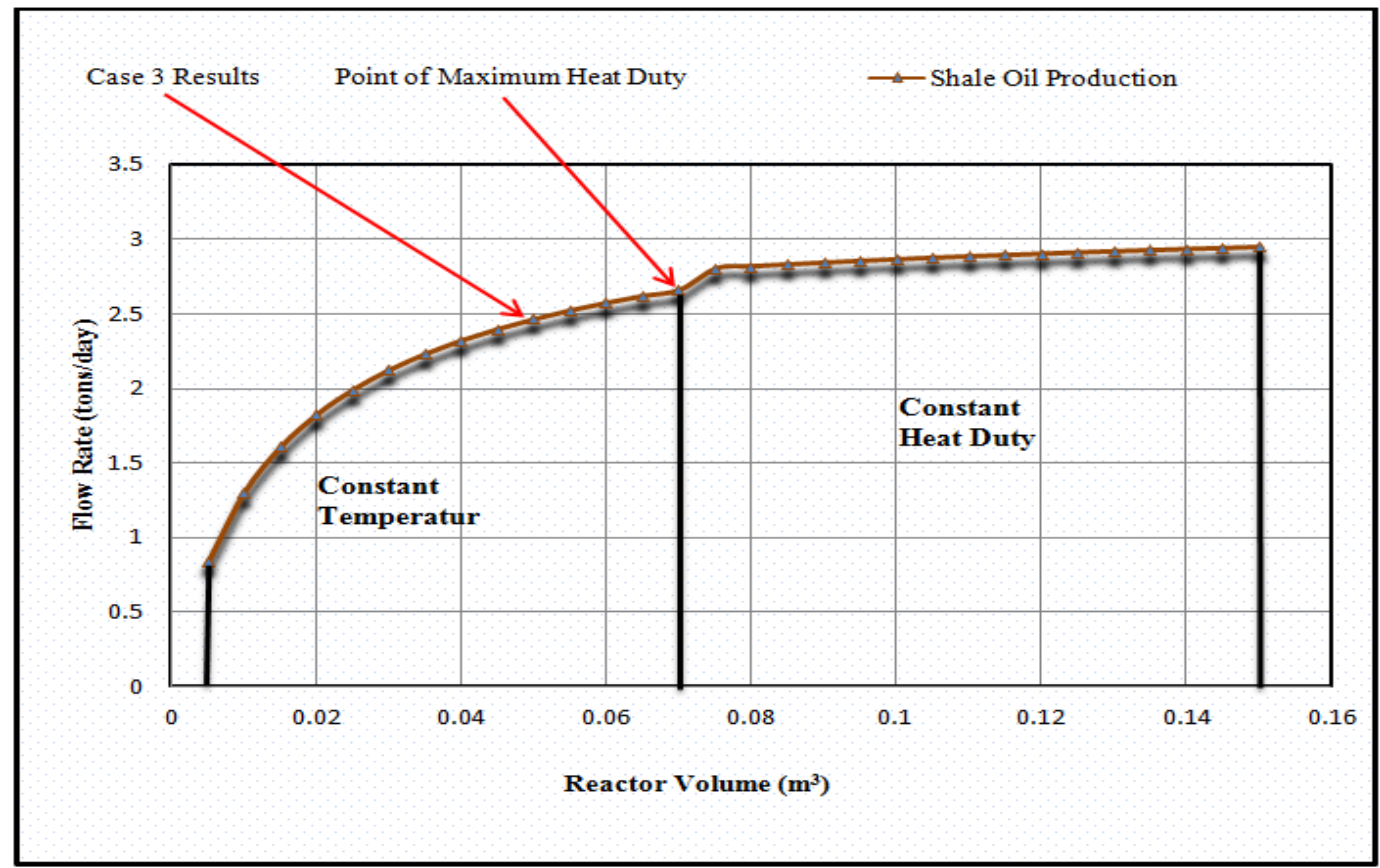

Figure 13 - Optimizing reactor volume 


\section{CONCLUSION}

Oil shale process model developed in Aspen presented the optimum operating parameters for maximum process yield. The single reactor equipment was simulated in four different zones separately. The Model Analysis Tool in Aspen has been used extensively to find the optimum operating conditions. Four different cases were studied to find the best treatment combination of important factors controlling process yield.

The first case investigated the reactor bed temperature where focus was more on temperature range of kerogen conversion and carbon dioxide formation with no limit on heat supply. As a result, the optimum reactor temperature was obtained in case 1 as well as a very good estimation of a range of working temperature considering the mineral decomposition reactions.

In case 2 , the best feed rate for maximum shale oil production was found for a given reactor volume with limited heat supply having the optimum reactor temperature found from case 1 . The shale oil production increased with increase in feed rate until the heat supply limit was reached.

After this point, shale oil production went down due to the decrease in the reactor temperature.

Case 3 was designed to find out the best optimum combination of reactor temperature and feed rate for maximum shale oil production for a given reactor volume with limited heat supply where the procedure for case 2 was repeated for different reactor temperatures. It was concluded that for a $0.05 \mathrm{~m}^{3}$ volume of reactor and a heat duty of $1.46 * \mathrm{E} 6 \mathrm{BTU} / \mathrm{hr}$ from natural gas burner, the optimum temperature was $458^{\circ} \mathrm{C}$ and the corresponding optimum flow rate was 40 tpd.

The effect of the volume of the reactor on the shale oil production for a constant feed rate with limited heat supply was studied in case 4 . For reactor volume of $0.05 \mathrm{~m}^{3}$ and flow rate of 40 tpd the shale oil yield was 2.68 tpd, but at $0.075 \mathrm{~m}^{3}$ volume where the heat duty limit was reached, the shale oil production had a $5 \%$ increase to 2.8 tpd.

\section{REFERENCES}

[1]. Klienberg, R. L. (2006). Oil Shale

[2]. King, H. (2005). Geoscience News and Information:

http://geology.com/rocks/shale.shtml

[3]. [3] San Leon Energy. (2014, October 08 ,

http://www.sanleonenergy.com/operationsand- assets/timahdit-oil-shale-bench-test.aspx

[4]. Sheritt, R., Jia, J., Meilani , P., \& Schmidt, J. (2009). Advances in steady-state process modeling of oil shale retorting. 29th Oil Shale Symposium.

[5]. Intitute for Energy Research, 2009 http://instituteforenergyresearch.org/studies/po licies-of-scarcity-in-a-land-of-plenty/

[6]. Stuart Oil Shale Project. (2014, August 03), http://en.wikipedia.org/wiki/Stuart_Oil_Shale_ Project

[7]. Crude Oil Peak. (2012, 04). http://crudeoilpeak.info/proudly-powered-byoil-shale

[8]. Speight, J. G. (2012). Shale Oil Production Processes

[9]. Winter, M. (20001). Spent Oil Shale use in Earthwork Construction. ScienceDirect

[10]. Smoot, \& Douglas. (2012). Demonstration of advanced technology for surface processing of oil shale.

[11]. Golpour H., Smith J. D., Oil Shale Ex-Situ Process - Leaching Study of Spent Shale, International Journal of Engineering Science Invention ||Volume 6 Issue 3|| March 2017 || PP. 45-53

[12]. Hendrickson, T. A. (1974). Oil shale processing methods. 7th Oil Shale Symposium

[13]. Singleton, M. F., Koskinas, G. J., Burnham, A. K., \& Raley, J. H. (1986). Assay Products from green river oil shale. Lawrence Livermore National Laboratory.

[14]. Diaz, J. C., \& Braun, R. L. (1984). Process simulation model for a staged, fluidizedbed oil shale retort using lift pipe combustor.

[15]. Aspen Plus. (2011). Model for Oil Shale Retorting Process 
Dr. Hassan Golpour et al. Int. Journal of Engineering Research and Application $\quad$ www.ijera.com ISSN: 2248-9622, Vol. 7, Issue 4, (Part -1) April 2017, pp.81-93

APPENDIX A

ASPEN SIMULATION OF OIL SHALE PYROLYSIS

Table 1 - Case 1: Feed Rate $=26$ tons/day

\begin{tabular}{|l|l|l|l|l|}
\hline $\begin{array}{l}\text { T } \\
\left({ }^{(} \mathbf{C}\right)\end{array}$ & $\begin{array}{l}\text { Light Gas } \\
\text { Production } \\
\text { (tons/day) }\end{array}$ & $\begin{array}{l}\text { Shale Oil } \\
\text { (tons/day } \\
\text { ) }\end{array}$ & $\begin{array}{l}\text { Consumed Natural } \\
\text { Gas (tons/day) }\end{array}$ & $\begin{array}{l}\text { Total CO } \\
\text { (tons/day) }\end{array}$ \\
\hline $\mathbf{3 5 0}$ & 0.005397614 & 0.06047 & 0.379166666 & 0.76035 \\
\hline $\mathbf{3 7 5}$ & 0.019363297 & 0.21692 & 0.470833333 & 0.88184 \\
\hline $\mathbf{4 0 0}$ & 0.050912595 & 0.57036 & 0.633333334 & 1.53147 \\
\hline $\mathbf{4 2 5}$ & 0.098933391 & 1.10833 & 0.883333332 & 3.31551 \\
\hline $\mathbf{4 5 0}$ & 0.144052289 & 1.61379 & 1.154166667 & 3.67853 \\
\hline $\mathbf{4 7 5}$ & 0.173805837 & 1.94711 & 1.383333332 & 3.9768 \\
\hline $\mathbf{5 0 0}$ & 0.191476074 & 2.14507 & 1.579166665 & 4.22348 \\
\hline $\mathbf{5 2 5}$ & 0.200718503 & 2.24861 & 1.741666666 & 4.42245 \\
\hline $\mathbf{5 5 0}$ & 0.20575479 & 2.30503 & 1.891666667 & 4.60242 \\
\hline $\mathbf{5 7 5}$ & 0.208468008 & 2.33542 & 2.033333334 & 4.77022 \\
\hline $\mathbf{6 0 0}$ & 0.209966308 & 2.35221 & 2.170833332 & 4.9319 \\
\hline $\mathbf{6 2 5}$ & 0.210826841 & 2.36185 & 2.308333334 & 5.0929 \\
\hline $\mathbf{6 5 0}$ & 0.211340521 & 2.3676 & 2.450000002 & 5.25838 \\
\hline $\mathbf{6 7 5}$ & 0.211644229 & 2.37101 & 2.591666665 & 5.42364 \\
\hline $\mathbf{7 0 0}$ & 0.211828958 & 2.37308 & 2.733333332 & 5.58877 \\
\hline $\mathbf{7 2 5}$ & 0.21194695 & 2.3744 & 2.879166668 & 5.75869 \\
\hline $\mathbf{7 5 0}$ & 0.21202346 & 2.37526 & 3.029166666 & 5.93341 \\
\hline $\mathbf{7 7 5}$ & 0.212072839 & 2.37581 & 3.179166667 & 6.10811 \\
\hline $\mathbf{8 0 0}$ & 0.212106193 & 2.37618 & 3.270833334 & 6.21487 \\
\hline $\mathbf{8 2 5}$ & 0.21212903 & 2.37644 & 3.333333334 & 6.28765 \\
\hline $\mathbf{8 5 0}$ & 0.212144566 & 2.37661 & 3.429166666 & 10.3983 \\
\hline $\mathbf{8 7 5}$ & 0.212155576 & 2.37674 & 3.491666665 & 10.4711 \\
\hline $\mathbf{9 0 0}$ & 0.212105886 & 2.37618 & 3.650000004 & 10.6554 \\
\hline $\mathbf{9 2 5}$ & 0.212128951 & 2.37644 & 3.812500008 & 10.8446 \\
\hline $\mathbf{9 5 0}$ & 0.212173214 & 2.37693 & 4.316666652 & 11.4316 \\
\hline $\mathbf{9 7 5}$ & 0.212176237 & 2.37697 & 4.487500008 & 11.6305 \\
\hline $\mathbf{1 0 0 0}$ & 0.212178565 & 2.37699 & 4.66666668 & 11.8391 \\
\hline & & & & \\
\hline
\end{tabular}

Table 2 - Case 2: $\quad \mathrm{T}=600^{\circ} \mathrm{C}$

\begin{tabular}{|l|l|l|l|l|}
\hline $\begin{array}{l}\text { Feed } \\
\text { Rate } \\
\text { (tons/day } \\
)\end{array}$ & $\begin{array}{l}\text { T } \\
\left({ }^{\circ} \mathbf{C}\right)\end{array}$ & $\begin{array}{l}\text { Heat Duty } \\
(\mathbf{W})\end{array}$ & $\begin{array}{l}\text { Shale Oil } \\
\text { (tons/day) }\end{array}$ & $\begin{array}{l}\mathbf{C O}_{2} \\
\text { (tons/day) }\end{array}$ \\
\hline $\mathbf{5}$ & 600 & 316321.002 & 0.445210326 & 0.006554043 \\
\hline $\mathbf{1 0}$ & 600 & 633829.404 & 0.893119717 & 0.013111188 \\
\hline $\mathbf{1 5}$ & 600 & 951636.59 & 1.34170827 & 0.01966911 \\
\hline $\mathbf{2 0}$ & 600 & 1269614.64 & 1.79068522 & 0.026227482 \\
\hline $\mathbf{2 5}$ & 550 & $1.46 \mathrm{E}+06$ & 2.213004 & 0.032760979 \\
\hline $\mathbf{3 0}$ & 513 & $1.46 \mathrm{E}+06$ & 2.50936109 & 0.004093126 \\
\hline $\mathbf{3 5}$ & 480 & $1.46 \mathrm{E}+06$ & 2.65403288 & 0.045708433 \\
\hline $\mathbf{4 0}$ & 455 & $1.46 \mathrm{E}+06$ & 2.68112764 & 0.051540326 \\
\hline $\mathbf{4 5}$ & 444 & $1.46 \mathrm{E}+06$ & 2.63851848 & 0.057391457 \\
\hline $\mathbf{6 0}$ & 416 & $1.46 \mathrm{E}+06$ & 2.55413322 & 0.064212705 \\
\hline
\end{tabular}


Dr. Hassan Golpour et al. Int. Journal of Engineering Research and Application $\quad$ www.ijera.com ISSN: 2248-9622, Vol. 7, Issue 4, (Part -1) April 2017, pp.81-93

Table 3 - Case 3: $\quad \mathrm{T}=350{ }^{\circ} \mathrm{C}$

\begin{tabular}{|l|l|l|l|l|}
\hline $\begin{array}{l}\text { Feed Rate } \\
\text { (tons/day) }\end{array}$ & $\begin{array}{l}\mathbf{T} \\
\left({ }^{\circ} \mathbf{C}\right)\end{array}$ & $\begin{array}{l}\text { Heat Duty } \\
(\mathbf{W})\end{array}$ & $\begin{array}{l}\text { Shale Oil } \\
\text { (tons/day) }\end{array}$ & $\begin{array}{l}\mathbf{C O}_{2} \\
\text { (tons/day) }\end{array}$ \\
\hline $\mathbf{5 0}$ & 350 & 567847.88 & 0.017805304 & 0.127426584 \\
\hline $\mathbf{1 0 0}$ & 350 & 1151836.02 & 0.0356191 & 0.332153065 \\
\hline $\mathbf{1 5 0}$ & 324.239403 & $1.46 \mathrm{E}+06$ & 0.053784776 & 0.134792029 \\
\hline $\mathbf{2 0 0}$ & 277.00078 & $1.46 \mathrm{E}+06$ & 0.06158315 & 0.008915642 \\
\hline $\mathbf{2 5 0}$ & 244.900855 & $1.46 \mathrm{E}+06$ & 0.091622027 & 0.001047754 \\
\hline
\end{tabular}

Table 4 - Case 3: $\mathrm{T}=400^{\circ} \mathrm{C}$

\begin{tabular}{|l|l|l|l|l|}
\hline $\begin{array}{l}\text { Feed Rate } \\
\text { (tons/day) }\end{array}$ & $\begin{array}{l}\mathbf{T} \\
\left({ }^{\circ} \mathbf{C}\right)\end{array}$ & $\begin{array}{l}\text { Heat Duty } \\
(\mathbf{W})\end{array}$ & $\begin{array}{l}\text { Shale Oil } \\
\text { (tons/day) }\end{array}$ & $\begin{array}{l}\mathbf{C O}_{2} \\
\text { (tons/day) }\end{array}$ \\
\hline $\mathbf{2 0}$ & 400 & 356544.226 & 0.361513563 & 0.025752094 \\
\hline $\mathbf{4 0}$ & 400 & 752590.756 & 0.881736143 & 0.051650763 \\
\hline $\mathbf{6 0}$ & 400 & 1166876.3 & 1.4752379 & 0.073777216 \\
\hline $\mathbf{8 0}$ & 400 & 1593575.78 & 2.11861528 & 0.098366199 \\
\hline $\mathbf{1 0 0}$ & 374.84 & $1.46 \mathrm{E}+06$ & 1.11314742 & 0.121128936 \\
\hline
\end{tabular}

Table 5 - Case 3: $\mathrm{T}=450{ }^{\circ} \mathrm{C}$

\begin{tabular}{|l|l|l|l|l|}
\hline $\begin{array}{l}\text { Feed Rate } \\
\text { (tons/day) }\end{array}$ & $\begin{array}{l}\mathbf{T} \\
\left({ }^{\circ} \mathbf{C}\right)\end{array}$ & $\begin{array}{l}\text { Heat Duty } \\
(\mathbf{W})\end{array}$ & $\begin{array}{l}\text { Shale Oil } \\
(\text { tons/day) }\end{array}$ & $\begin{array}{l}\mathbf{C O}_{2} \\
(\text { tons/day) }\end{array}$ \\
\hline 10 & 450 & 312059.165 & 0.523697584 & 0.012664713 \\
\hline 20 & 450 & 652305.057 & 1.14390557 & 0.026103949 \\
\hline 30 & 450 & 1001821.49 & 1.79585558 & 0.040234904 \\
\hline 40 & 450 & 1356943.81 & 2.46699994 & 0.05107623 \\
\hline 50 & 433.23 & $1.46 \mathrm{E}+06$ & 2.55413322 & 0.063388944 \\
\hline 60 & 416.72 & $1.46 \mathrm{E}+06$ & 2.31537283 & 0.077190055 \\
\hline
\end{tabular}

Table 6 - Case 3: $\quad \mathrm{T}=500{ }^{\circ} \mathrm{C}$

\begin{tabular}{|l|l|l|l|l|}
\hline $\begin{array}{l}\text { Feed Rate } \\
\text { (tons/day) }\end{array}$ & $\begin{array}{l}\text { T } \\
\left({ }^{\circ} \mathbf{C}\right)\end{array}$ & $\begin{array}{l}\text { Heat Duty } \\
(\mathbf{W})\end{array}$ & $\begin{array}{l}\text { Shale Oil } \\
\text { (tons/day) }\end{array}$ & $\begin{array}{l}\mathbf{C O}_{2} \\
\text { (tons/day) }\end{array}$ \\
\hline 10 & 500 & 449362.773 & 0.779463039 & 0.01334808 \\
\hline 20 & 500 & 912734.088 & 1.60033669 & 0.025760898 \\
\hline 30 & 500 & 1379901.21 & 2.43243112 & 0.040178714 \\
\hline 40 & 458.99 & $1.46 \mathrm{E}+06$ & 2.68112764 & 0.052189279 \\
\hline 50 & 444.33 & $1.46 \mathrm{E}+06$ & 2.63851848 & 0.056670717 \\
\hline 60 & 433.23 & $1.46 \mathrm{E}+06$ & 2.55413322 & 0.062963278 \\
\hline
\end{tabular}

Table 7 - Case 3: $\mathrm{T}=550{ }^{\circ} \mathrm{C}$

\begin{tabular}{|l|l|l|l|l|}
\hline $\begin{array}{l}\text { Feed Rate } \\
\text { (tons/day) }\end{array}$ & $\begin{array}{l}\mathbf{T} \\
\left({ }^{\circ} \mathbf{C}\right)\end{array}$ & $\begin{array}{l}\text { Heat Duty } \\
(\mathbf{W})\end{array}$ & $\begin{array}{l}\text { Shale Oil } \\
\text { (tons/day) }\end{array}$ & $\begin{array}{l}\mathbf{C O}_{2} \\
\text { (tons/day) }\end{array}$ \\
\hline 5 & 550 & 272586.788 & 0.428574492 & 0.006647613 \\
\hline 10 & 550 & 548438.928 & 0.865574105 & 0.001367061 \\
\hline 15 & 550 & 825130.721 & 1.30474015 & 0.019968887 \\
\hline 20 & 550 & 1102304.36 & 1.74514943 & 0.026632613 \\
\hline 25 & 550 & 1379807.65 & 2.18640927 & 0.033297463 \\
\hline 30 & 513.19 & $1.46 \mathrm{E}+06$ & 2.50936109 & 0.039797862 \\
\hline 35 & 480.06 & $1.46 \mathrm{E}+06$ & 2.65403288 & 0.004749788 \\
\hline 40 & 458.99 & $1.46 \mathrm{E}+06$ & 2.68112764 & 0.051158858 \\
\hline 45 & 444.33 & $1.46 \mathrm{E}+06$ & 2.63851848 & 0.057200293 \\
\hline 50 & 433.23 & $1.46 \mathrm{E}+06$ & 2.55413322 & 0.063180657 \\
\hline
\end{tabular}


Dr. Hassan Golpour et al. Int. Journal of Engineering Research and Application $\quad$ www.ijera.com ISSN: 2248-9622, Vol. 7, Issue 4, (Part -1) April 2017, pp.81-93

Table 8 - Case 3: $\mathrm{T}=600{ }^{\circ} \mathrm{C}$

\begin{tabular}{|l|l|l|l|l|}
\hline $\begin{array}{l}\text { Feed Rate } \\
\text { tons/day) }\end{array}$ & $\begin{array}{l}\text { T } \\
\left({ }^{\circ} \mathbf{C}\right)\end{array}$ & $\begin{array}{l}\text { Heat Duty } \\
(\mathbf{W})\end{array}$ & $\begin{array}{l}\text { Shale Oil } \\
(\text { tons/day) }\end{array}$ & $\begin{array}{l}\mathbf{C O}_{2} \\
\text { (tons/day) }\end{array}$ \\
\hline 5 & 600 & 316321.002 & 0.445210326 & 0.006554043 \\
\hline 10 & 600 & 633829.404 & 0.893119717 & 0.013111188 \\
\hline 15 & 600 & 951636.59 & 1.34170827 & 0.01966911 \\
\hline 20 & 600 & 1269614.64 & 1.79068522 & 0.026227482 \\
\hline 25 & 550 & $1.46 \mathrm{E}+06$ & 2.213004 & 0.032760979 \\
\hline 30 & 513 & $1.46 \mathrm{E}+06$ & 2.50936109 & 0.004093126 \\
\hline 35 & 480 & $1.46 \mathrm{E}+06$ & 2.65403288 & 0.045708433 \\
\hline 40 & 455 & $1.46 \mathrm{E}+06$ & 2.68112764 & 0.051540326 \\
\hline 45 & 444 & $1.46 \mathrm{E}+06$ & 2.63851848 & 0.057391457 \\
\hline 60 & 416 & $1.46 \mathrm{E}+06$ & 2.55413322 & 0.064212705 \\
\hline
\end{tabular}

Table 9 - Case 4: $\quad \mathrm{T}=450{ }^{\circ} \mathrm{C} \quad$ Feed Rate $=40$ tons $/$ day

\begin{tabular}{|c|c|c|c|c|}
\hline $\begin{array}{l}\text { Volume of } \\
\text { Reactor }\left(\mathbf{m}^{3}\right)\end{array}$ & $\begin{array}{l}\mathbf{T} \\
\left({ }^{\circ} \mathbf{C}\right)\end{array}$ & $\begin{array}{l}\text { Heat Duty } \\
(W)\end{array}$ & $\begin{array}{l}\text { Shale Oil } \\
\text { (tons/day) }\end{array}$ & $\begin{array}{l}\mathrm{CO}_{2} \\
\text { (tons/day) }\end{array}$ \\
\hline 0.005 & 450 & 862486.046 & 0.843076064 & 0.046760115 \\
\hline 0.010 & 450 & 997773.799 & 1.30629675 & 0.047352165 \\
\hline 0.015 & 450 & 1086393.97 & 1.6097292 & 0.047977911 \\
\hline 0.020 & 450 & 1150101.13 & 1.82786037 & 0.048076019 \\
\hline 0.025 & 450 & 1198652.46 & 1.99409848 & 0.048117828 \\
\hline 0.030 & 450 & 1237176.31 & 2.12600284 & 0.048827695 \\
\hline 0.035 & 450 & 1268663.09 & 2.23381251 & 0.049362923 \\
\hline 0.040 & 450 & 1294990.27 & 2.32395589 & 0.048680639 \\
\hline 0.045 & 450 & 1317403.89 & 2.40069937 & 0.048741027 \\
\hline 0.050 & 450 & 1336767.57 & 2.46699994 & 0.048781726 \\
\hline 0.055 & 450 & 1353701.09 & 2.52497976 & 0.048809148 \\
\hline 0.060 & 450 & 1368662.22 & 2.57620616 & 0.049848431 \\
\hline 0.065 & 450 & 1381997.25 & 2.62186483 & 0.049059075 \\
\hline 0.070 & 450 & 1393973.54 & 2.66287126 & 0.04910593 \\
\hline 0.075 & 455.11 & $1.46 \mathrm{E}+06$ & 2.80703063 & 0.049267388 \\
\hline 0.080 & 454.24 & $1.46 \mathrm{E}+06$ & 2.82070063 & 0.049282417 \\
\hline 0.085 & 453.42 & $1.46 \mathrm{E}+06$ & 2.83347647 & 0.049296417 \\
\hline 0.090 & 452.66 & $1.46 \mathrm{E}+06$ & 2.84546293 & 0.04930951 \\
\hline 0.095 & 451.94 & $1.46 \mathrm{E}+06$ & 2.85674754 & 0.0493218 \\
\hline 0.100 & 451.27 & $1.46 \mathrm{E}+06$ & 2.86740415 & 0.049333373 \\
\hline 0.105 & 450.63 & $1.46 \mathrm{E}+06$ & 2.87749564 & 0.0493443 \\
\hline 0.110 & 450.03 & $1.46 \mathrm{E}+06$ & 2.88707597 & 0.049354644 \\
\hline 0.115 & 449.46 & $1.46 \mathrm{E}+06$ & 2.8961918 & 0.049364469 \\
\hline 0.120 & 448.91 & $1.46 \mathrm{E}+06$ & 2.90488374 & 0.049373808 \\
\hline 0.125 & 448.40 & $1.46 \mathrm{E}+06$ & 2.91318735 & 0.049382711 \\
\hline 0.130 & 447.90 & $1.46 \mathrm{E}+06$ & 2.92113396 & 0.049391211 \\
\hline 0.135 & 447.43 & $1.46 \mathrm{E}+06$ & 2.92875127 & 0.049399338 \\
\hline 0.140 & 446.98 & $1.46 \mathrm{E}+06$ & 2.93606394 & 0.049407126 \\
\hline 0.145 & 446.54 & $1.46 \mathrm{E}+06$ & 2.94309396 & 0.049414599 \\
\hline 0.150 & 446.12 & $1.46 \mathrm{E}+06$ & 2.94986109 & 0.049421778 \\
\hline 0.155 & 445.72 & $1.46 \mathrm{E}+06$ & 2.95638307 & 0.04942868 \\
\hline 0.160 & 445.33 & $1.46 \mathrm{E}+06$ & 2.96267596 & 0.04943533 \\
\hline 0.165 & 444.96 & $1.46 \mathrm{E}+06$ & 2.9687543 & 0.049441738 \\
\hline 0.170 & 444.60 & $1.46 \mathrm{E}+06$ & 2.97463131 & 0.049447927 \\
\hline 0.175 & 444.25 & $1.46 \mathrm{E}+06$ & 2.98031903 & 0.049453901 \\
\hline 0.180 & 443.92 & $1.46 \mathrm{E}+06$ & 2.98582848 & 0.049459683 \\
\hline
\end{tabular}


Dr. Hassan Golpour et al. Int. Journal of Engineering Research and Application www.ijera.com ISSN: 2248-9622, Vol. 7, Issue 4, (Part -1) April 2017, pp.81-93

Table 9 (Cont.)

\begin{tabular}{|c|c|c|c|c|}
\hline $\begin{array}{l}\text { Volume of Reactor } \\
\left(\mathbf{m}^{3}\right)\end{array}$ & $\begin{array}{l}\mathbf{T} \\
\left({ }^{\circ} \mathbf{C}\right) \\
\end{array}$ & $\begin{array}{l}\text { Heat Duty } \\
(\mathrm{W})\end{array}$ & $\begin{array}{l}\text { Shale Oil } \\
\text { (tons/day) }\end{array}$ & $\begin{array}{l}\mathrm{CO}_{2} \\
\text { (tons/day) }\end{array}$ \\
\hline 0.185 & 443.59 & $1.46 \mathrm{E}+06$ & 2.99117 & 0.04947 \\
\hline 0.19 & 443.27 & $1.46 \mathrm{E}+06$ & 2.99635 & 0.04947 \\
\hline 0.195 & 442.97 & $1.46 \mathrm{E}+06$ & 3.00138 & 0.04948 \\
\hline 0.2 & 442.67 & $1.46 \mathrm{E}+06$ & 3.00627 & 0.04948 \\
\hline 0.205 & 442.38 & $1.46 \mathrm{E}+06$ & 3.01103 & 0.04949 \\
\hline 0.21 & 442.1 & $1.46 \mathrm{E}+06$ & 3.01565 & 0.04949 \\
\hline 0.215 & 441.83 & $1.46 \mathrm{E}+06$ & 3.02016 & 0.0495 \\
\hline 0.22 & 441.56 & $1.46 \mathrm{E}+06$ & 3.02454 & 0.0495 \\
\hline 0.225 & 441.31 & $1.46 \mathrm{E}+06$ & 3.02882 & 0.0495 \\
\hline 0.23 & 441.06 & $1.46 \mathrm{E}+06$ & 3.03299 & 0.04951 \\
\hline 0.235 & 440.81 & $1.46 \mathrm{E}+06$ & 3.03706 & 0.04951 \\
\hline 0.24 & 440.57 & $1.46 \mathrm{E}+06$ & 3.04103 & 0.04952 \\
\hline 0.245 & 440.34 & $1.46 \mathrm{E}+06$ & 3.04491 & 0.04952 \\
\hline 0.25 & 440.11 & $1.46 \mathrm{E}+06$ & 3.0487 & 0.04952 \\
\hline 0.255 & 439.89 & $1.46 \mathrm{E}+06$ & 3.05241 & 0.04953 \\
\hline 0.26 & 439.67 & $1.46 \mathrm{E}+06$ & 3.05603 & 0.04953 \\
\hline 0.265 & 439.46 & $1.46 \mathrm{E}+06$ & 3.05958 & 0.04954 \\
\hline 0.27 & 439.25 & $1.46 \mathrm{E}+06$ & 3.06305 & 0.04954 \\
\hline 0.275 & 439.05 & $1.46 \mathrm{E}+06$ & 3.06645 & 0.04954 \\
\hline 0.28 & 438.85 & $1.46 \mathrm{E}+06$ & 3.06978 & 0.04955 \\
\hline 0.285 & 438.66 & $1.46 \mathrm{E}+06$ & 3.07304 & 0.04955 \\
\hline 0.29 & 438.47 & $1.46 \mathrm{E}+06$ & 3.07624 & 0.04955 \\
\hline 0.295 & 438.28 & $1.46 \mathrm{E}+06$ & 3.07937 & 0.04956 \\
\hline 0.3 & 438.1 & $1.46 \mathrm{E}+06$ & 3.08244 & 0.04956 \\
\hline
\end{tabular}

